\title{
Impact of Flexible Working Arrangements in the Public Sector in Indonesia
}

\author{
Andi Aisyah Nurul Alifyanti Hidayah \\ Asia Pacific University of Technology and Innovation \\ Jugindar Singh Kartar Singh \\ Asia Pacific University of Technology and Innovation \\ Ibiwani Alisa Hussain \\ Asia Pacific University of Technology and Innovation
}

Received: Feb. 6, 2021 Accepted: Mar. 1, 2021 Online published: Mar. 26, 2021

doi:10.5296/ijhrs.v11i2.18458 URL: https://doi.org/10.5296/ijhrs.v11i2.18458

\begin{abstract}
The aim of this article is to examine the impact of flexible working arrangements in the public sector in Indonesia. From a theoretical perspective, this study examines the influence of flexible working arrangements on work-life conflict, work pressure, and organizational commitment. The focus is on employees engaged in the public sector in Indonesia as it regards this as a gap in current research. Most past studies on flexible working arrangements concentrate on large corporations in developed countries. There is a dearth of studies on the impact of flexible working arrangements on employee work-related outcomes in the public sector in Indonesia. In addition, empirical evidence concerning the association between flexible working arrangements and employee outcomes such as work-family conflict and organizational commitment shows inconsistent and mixed results. This was a quantitative study that used a survey method to collect data from 400 respondents. Descriptive and inferential statistics were generated using the SPSS software. The result showed that only organizational commitment was significantly correlated with flexible working arrangements. Work-family conflict and work pressure did not show a significant association with flexible work arrangements. This deviation from past studies could be attributed to cultural differences and policies in the public sector. This study provided new insights to organizations and human resource managers on the effect of the outcomes of flexible working arrangements. The findings revealed in this study are unique, and they provide support for the
\end{abstract}


theory that flexible working conditions lead to increased organizational commitment. In terms of originality, past literature on flexible working arrangements mainly concentrates on large corporations or the private sector. With the growing importance of flexible working arrangements, there is a need to focus on the public sector.

Keywords: Flexible working arrangement, civil servant, public sector, work-family conflict, work pressure, organizational commitment.

\section{Introduction}

\subsection{Background}

Indonesia is a large country and the world's fourth most populous, with a population of around 270 million. Indonesia is also the largest economy in Southeast Asia. Indonesia's economy shows an uptrend, and the GDP grew from USD755b in 2010 to 1.042 trillion in 2018 (The World Bank, 2018). The country's development plan, referred to as 'Rencana Pembangunan Jangka Menengah Nasional', aims to further strengthen Indonesia's economy by improving its human capital and competitiveness in the global market (The World Bank, 2020). Such an effort is critical to ensure Indonesia has a strong and productive human capital. The Indonesian civil service has expanded by $25 \%$ in the last 12 years. It employs approximately $1.7 \%$ of Indonesia's population in 29 national, regional, and local government agencies. The recent growth provides an opportunity for the Indonesian government to work towards its goal of enhancing the social welfare of Indonesians. In order to accomplish this goal, it is essential to ensure that the country's civil servants are competent and effective to maximize their contributions to Indonesian society (The World Bank, 2018a). In order to improve the performance and productivity of employees, the Indonesian civil service is expected to play a critical role. During this era of globalization, the government of Indonesia needs to implement reforms. The reforms encompass improvement in the structure of its bureaucracy, both in terms of enhancing the competencies and quality of government employees and developing an up-to-date modern and efficient government system (Tjiptoherijanto, 2018). However, there are concerns expressed related to the performance of employees in Indonesia.

Concerns related to productivity and performance have been raised concerning the productivity of employees in Indonesia. According to the World Bank's Human Capital Index, Indonesia's next generation will only be $54 \%$ as productive as she or he could have been with full health and complete education. Indonesia adopted the Human Capital Project, which is a global effort to improve more and better investments in people for greater equity and economic growth (The World Bank, 2020). Although the number of civil servants is high, many civil servants' performance in Indonesia is considered low and often missed the Ministry's target (Saputra, 2018). It was reported that more than $64 \%$ of the civil servants have a low level of skills and knowledge, and they are poorly deployed across the country. (Putra, 2016). With a high demand for work, there are many problems that arise regarding the Indonesian civil service's performance. A 2017 survey concluded that the civil servant's enrolment system was considered to be one of the two most corrupted sectors (Matondang, 2017). Employees in Indonesia's public sector have been given the benefits and flexible work 
options, but there are no visible positive returns in performance. Therefore, to achieve a cleaner and more efficient civil service, Indonesia needs to implement civil service reforms (Tjiptoherijanto, 2018).

\subsection{Problem Statement}

Researchers and scholars have stated that flexible working arrangement is one solution to improve productivity and other work-related outcomes of employees (Solanki, 2013, Hofäcker, and König 2013). Due to the Covid19 pandemic, the implemented flexible working arrangements are gaining acceptance and could be a longer-term solution to overcome stress and other outcomes (Thevamanohar, 2020). A survey found that $69 \%$ of millennials and $64 \%$ of Gen Z stated that they agree to work from home in the future, which will lead to lower stress (Thevamanohar, 2020). Flexible working arrangements enable employees to balance their work-family roles and execute their work-related tasks efficiently. This leads to improved productivity and other positive outcomes (Solanki, 2013). One of the issues faced is work-family balance, and women reported more significant work-family conflict and family-work conflict than men. There is a significant increase in female participation in the Indonesian labour force (U.N. Women, 2012), which results in an increase in the number of dual incomes earning households (Ridho \& Al Rasyid, 2010), making the work-family balance an important community and economic issue in Indonesia (Afrianty, 2013). Studies have also found that irregularity and unpredictability of working hours have a negative impact on the work-family conflict of employees (Hofäcker and König, 2013). The work-family conflict leads to stress, burnout, anxiety, ill-health, and some of the other working mothers' challenges (Kremer, 2016). Flexible working arrangements lead to other positive outcomes such as work commitment (Hofäcker and König 2013), work-family conflict (Choo, Desa and Asaari, 2016), and job satisfaction (Masuda et al., 2012).

However, evidence from past studies has shown inconsistent and contradictory results. Evidence from past studies mostly suggests that flexible working time reduces work-family conflict (Choo, Desa, and Asaari, 2016; Dex \& Smith, 2002). However, a study by Allard, Haas, and Philip Hwang (2007) revealed that the availability of flexible working hours had no effect on work-to-family conflict experienced by managerial fathers. Studies have also shown that flexible work arrangements can lead to a higher level of job satisfaction, better work-family balance, and lower stress levels (Kelliher and Anderson, 2010; Shagvaliyeva and Yazdanifard, 2014; Haley and Miller 2015). However, other researchers and scholars have argued that this could be due to other factors. Russel et al. (2007) argued that the variation could also depend on the nature of the flexible work initiative (Russell et al., 2007). Loft (2017) argued that employees with sufficient job resources could eventually adapt to high job demands and are able to deal with work pressure. In addition, the employee's job control ability is also generally considered a resource to cope with work pressure (Lott, 2017). This shows that the results from past studies are inconsistent and debatable.

The evidence from past literature shows that flexible working arrangements feature prominently among the strategies used to build employees' commitment and competencies. Therefore, there is an overwhelming need for the public sector in Indonesia to start looking at 
the successful implementation of flexible working arrangements. However, there is a dearth of research and literature relating to the influence of flexible working arrangements on employees' work pressure, work-family conflict, and organizational commitment in Indonesia's public sector. In addition, evidence from past studies shows inconsistent and mixed results. Based on the importance of flexible working arrangements, this study examined the correlation between the implementation of flexible working arrangements and work-family conflict situation, their work pressure in the office, as well as their organizational commitment level of civil servants in Indonesia. The study makes a practical and theoretical contribution by examining the relationship between flexible working arrangements and work-family conflict situation, their work pressure in the office, as well as their organizational commitment. The evidence from this study will help employers implement work flexibility arrangements that are tailored to meet the current needs of employees. Past literature on flexible working arrangements mainly concentrates on large corporations or the private sector in terms of originality. This study provides evidence on the impact of flexible work arrangements in the public sector.

\section{Literature Review}

\subsection{Flexible Working Arrangement}

Due to globalization and other changes, flexible working arrangements is gaining acceptance by several organizations. Flexible working arrangements have been defined differently by scholars and researchers. Hill et al. (2008) referred to flexible working arrangements as the extent to which employees can change the time and place or when, where they engage in work-related activities and how their work is performed on a regular basis. Similarly, Kossek and Michel (2011) referred to flexible working arrangements as the choice given to employees to agree with employers when, when, or where they are engaged in work for various time periods. O'Driscoll and Kalliath (2004) referred to flexible work arrangements as a way to allow employees to balance their work and non-work-related demands. In this case, the demands encompass breaks from work, compressed workdays, telecommunications, and part-time work. Russel et al. (2007) further added that flexible working arrangement covers a wide range of organizations' initiatives to support work-family balance such as flexitime, working from home that encompasses telecommuting and teleworking, job sharing, and part-time work. Based on the definitions, the flexible working arrangement has multiple dimensions. It is not just the choice of time or place of work but also covers working from home, job sharing, career breaks that offer convenience to employees in planning working hours and achieve work-family balance (Torrington et al., 2011; Shagvaliyeva \& Yazdanifard, 2014).

Based on the perceived organizational support theory, flexible working arrangements indicate the employer's values and care about employees (Takeuchi et al., 2009). The employees would, therefore, reciprocate more favourably to the employers that provide flexible work arrangements. Researchers and scholars have stated that the provision of flexible working arrangements leads to several positive outcomes that include job satisfaction, commitment, return on labour, and retention of employees (Russell et al., 2007; Kotey and Sharma, 2019; 
Anderson and Keller, 2009; Posthuma et al., 2013; Cegarra-Leiva et al., 2012; Wang et al., 2011). Anderson and Kelliher (2009) stated that flexible work arrangements improve employee loyalty levels because they can meet their demands and improve their job satisfaction and commitment. Flexible work arrangements also improve an organization's return on labour (ROL) (Koyey and Sharma, 2019). Russel et al. (2007) added that organizations' flexibility is essential for employees to balance work and other commitments. This provision is based on the assumption that these arrangements can benefit the employees and the organization (Russell et al., 2007). A study by Kwon, Cho, and Song (2019) revealed that organizations should be aware of organizational culture and support. The study found that supervisory support will lead to participation in flexible work arrangements. However, organizations' hierarchical organizational culture can be an impediment to employee's participation in flexible working arrangements. In addition, some studies did not find any positive association between flexible working arrangements and employee work-related outcomes such as turnover intentions (Lee and Hong, 2011; Nikbakhsh, Afarinesh Khaki, and Sharififar, 2020). Another interesting finding by Masuda et al. (2012) showed that in countries that observe collective cultures, flexible work arrangement was not particularly observed or valued. Timms et al. (2015) further added that workplace cultural norms are essential for successfully implementing flexible work arrangements. Therefore, the outcomes associated with implementing flexible working arrangements in Indonesia are subject to further analysis. The environmental factors given by the current Indonesian civil servant's current state might reveal different findings for this study compared to the previous findings.

\subsection{Flexible Working Arrangements and Work-Family Conflict}

Work-family conflict is continuing to gain prominence amongst researchers and scholars. Several studies have shown that work-family is strongly associated with work-related outcomes such as health, stress, and burnout (Kremer, 2016; Hämmig, and Bauer, 2014). A study by Hämmig and Bauer (2014) found that work-family conflict was strongly associated with health outcomes and was consistently one of the strongest among the risk factors. Studies have also shown that work-family conflict affects women more than men. A study by Kremer (2016) revealed that men had lower work-family conflict compared to women. In addition to work-related tasks, women handle a big portion of family-related tasks (Yapp, 2018). The study by Yapp (2018) reported that women spent three times longer time doing household chores than men. This is a matter of concern because work-family conflict leads to negative health-related outcomes such as s to stress, burnout, anxiety, and ill-health.

Evidence from past studies suggests that flexible working time reduces work-family conflict (Choo, Desa, and Asaari, 2016; Dex \& Smith, 2002). The study by Choo, Desa, and Asaari (2016) found that flexible working arrangements had a significant and positive effect on work-family conflict. The flexible working arrangement that includes flexible working hours has been associated with lower work-family conflict and employee participation in work and non-work-related activities (Berg et al., 2014; Bohle, 2016). Specifically, flexible working hours were found to be linked strongly to reducing work-family conflict, with evidence of cultural differences in the effect (Masuda et al., 2012). White et al. (2003) also tested the impact of several measures that allow employee discretion in starting and finishing times. 


\section{$\triangle$ Macrothink}

The study found that flexible working arrangements, in general, reduce work-family conflict. Furthermore, the study revealed that men might utilize flexible working arrangements to increase working hours, thus exacerbating work-family conflict. Hyman et al. (2003) also cautioned against the use of flexible working arrangements to reduce work-family conflict. Some studies have even found no association between flexible working hours and work-family conflict (Allard, Haas, and Philip Hwang, 2007). The study by Allard, Haas, and Philip Hwang (2007) revealed that the availability of flexible working hours had no effect on work-to-family conflict experienced by managerial fathers. Generally, the past studies depicted those flexible working arrangements as a tool to reduce work-family conflict, but some inconsistencies and inconclusive findings were revealed in some other studies. In this study, the following hypothesis was developed to test the association between flexible working arrangements and work-family conflict:

H1: There is a correlation between flexible working arrangements and work-family conflict among employees in Indonesia's public sector.

\subsection{Flexible Working Arrangements and Work Pressure}

Another problem encountered by employees is work pressure that is related to stress and exhaustion (Rendon, 2016). Again, this is more prevalent amongst women, mainly due to job spill-over. Studies have shown that work spill-over to home lead to health and mental health-related problems (Grice, 2011). This problem is even greater in working mothers. Ramasamy (2019) stated that working mothers are highly stressed. This was further supported in a study by Sundaresan (2014), which showed that $67 \%$ of working mothers who were respondents to the study suffer from the effects of excessive work burden. The excessive work and the related imbalance in their life lead to feelings of exhaustion and stress. Past research has shown that work pressure and stress are related to negative outcomes such as job satisfaction, health, employee turnover, and productivity (Ajayi and Abimbola, 2013; Mansoor et al., 2011). A study by Mansoor et al. 2011 found that job stress had an inverse relationship with job satisfaction. Similarly, another study by (Ajayi and Abimbola, 2013) found that there was an inverse relationship between stress and employee performance. The study also revealed that there was an inverse relationship between stress and job satisfaction.

Studies have shown that flexible working arrangements can lead to lower work pressure and other related outcomes. A study by Kelliher and Anderson (2010) showed that employees with flexible work arrangements had greater levels of job satisfaction and organizational commitment than employees without flexible work arrangements. In addition, flexible working arrangements promote and facilitate work-family balance. Shagvaliyeva and Yazdanifard (2014) added that flexible working hours promote better employee work-family balance, leading to improved employee well-being. Haley and Miller (2015) added that a higher level of flexibility was associated with reductions in the probability of being stressed. Atkinson, Lucas, and Hall (2011) further added that flexible working appeared as highly salient and influenced respondents' attitudes. The study found that flexible working was linked to happiness and further promoted active states such as being pleased and cheerful among employees. However, there is some ambiguity from previous studies. It was shown that work pressure could be heterogeneously related to flexible working arrangements in a 
way where the policy can help reduce pressure for some employees while increasing the pressure for others. Kattenbach, Demerouti, and Nachreiner (2010) tested a two-factor flexibility structure, namely time-autonomy and time-restrictions. The results showed that the time restriction factor increased the level of exhaustion. The variation can also depend on the flexible work initiative's nature (Russell et al., 2007). In addition, employees with sufficient job resources can eventually adapt to high job demands and are able to deal with work pressure (Lott, 2017). The employee's job control ability is also generally considered a resource to cope with work pressure (Lott, 2017). Job control here refers to schedule control that includes flexitime and working-time autonomy. In this study, the following hypothesis was developed to test the association between flexible working arrangements and work-family conflict:

$\mathrm{H} 2$ : There is a correlation between flexible working arrangements and work pressure among employees in Indonesia's public sector.

\subsection{Flexible Working Arrangements and Organizational Commitment}

The organizational commitment of employees is an essential component of organizational behaviour. Organizational commitment is multidimensional, and scholars and researchers have defined it in several different ways. From the psychological perspective, organizational commitment "a force that binds an individual to a course of action of relevance to one or more aims" (Meyer \& Herscovitch, 2001, p 301). Yoo and Kim (2016) referred to organizational commitment as the extent or degree of an employee's psychological assimilation and sense of unity towards his or her employer. Ghani et al. (2004) explained that the level of organizational commitment would influence their decisions pertaining to continued employment with the organization (Ghani et al., 2004). Organizational commitment is also multidimensional. The three dimensions of organizational commitment are affective commitment, continuance commitment, and normative commitment (Meyer and Allen, 1991). Affective commitment refers to the employee's emotional attachment and identification with the organization (Meyer and Allen, 1991). Higher levels of affective commitment will be developed if the employees have shared a common goal and will work towards achieving the goals (Ketchand and Strawser, 2001). Continuance commitment refers to awareness of the cost associated with quitting the organization by employees (Meyer and Allen, 1991). Employees will develop higher continuance commitment levels if they have invested a large sum of side-bets (Meyer and Herscovitch, 2001). The feeling of obligation to continue employment and remain loyal is referred to as normative employment (Meyer and Allen, 1991). Employees will develop normative commitment in return for the employer's rewards and benefits (Meyer and Herscovitch, 2001).

Past researchers have identified the association between flexible work practices and organizational commitment (Ross and Ali, 2017; Gudep, 2019; Choo Desa and Asaari, 2019). Ross and Ali (2017) examined the commitment factors amongst ICT workers and found that flexible work arrangements had a positive and significant relationship with normative commitment. Gudep (2019) examined the relationship between teachers' flexible work systems and found that their flexible work system directly affected organizational commitment. Another study by Kwon (2019) revealed that turnover intention was 
significantly negatively correlated with flexible work systems and organizational commitment among nurses. The past studies point to the necessity to provide employees with flexible working arrangements to increase their organizational commitment. In this study, the following hypothesis was developed to test the association between flexible working arrangements and work-family conflict:

H3: There is a correlation between Flexible Working Arrangements and organizational commitment among employees in Indonesia's public sector.

\section{Method}

\subsection{Introduction and Research Design}

This quantitative study used positivism as a basic philosophy. Positivism was more appropriate because objective information was available. The hypotheses were developed, and measurements were also available. A deductive approach is deemed the most fitting as the nature of this study was to prove the causal relationship between variables, where the theories were the basis of the explanation. The data collection was one snapshot, and as such, this study was cross-sectional. A survey strategy was used to collect primary data. The target population was employees in the public sector in Indonesia. A structured questionnaire with closed-ended questions was distributed to respondents to measure the respondents' perception and attitude based on a 5-point Likert scale (Sekaran and Bougie, 2016). Convenience sampling and snowball sampling were chosen to collect data as it is difficult for the researcher to develop a sampling frame. After editing and coding the data, the SPSS software was used for data analysis.

\subsection{Population, Sampling, and Sample Size}

Saunders, Lewis, and Thornhill (2016) defined population as the elements from which a sample is taken. In this study, the target population was Indonesian civil servants or public sector employees, specifically in Indonesia. Sampling was done to select an appropriate number of elements from the population, which correctly represent the population (Sekaran and Bougie, 2016). This study used the formula offered by Tabachnick and Fidell (2007) for computing the sample size required for a multiple regression analysis that is $[\mathrm{N} \geq 50+8 \mathrm{~m}]$ wherein $\mathrm{m}=$ the number of predictor variables. As in this study number of variables was 4 , the minimum sample size was calculated as 74. Based on Krejcie and Morgan (1970) formula, the sample size should be at least 384 . Therefore, for better accuracy of findings, the sample size was set at 384 .

\subsection{Instrumentation And Questionnaire Design}

A self-administered structured questionnaire was chosen due to its convenience, low cost, reduced biases, and greater anonymity (Saunders et al., 2016). There were two parts to the design of the questionnaire. The first part asked the respondents about their demographic characteristics: the ministry they work with, where they are located in Indonesia, age group, gender, and marital status. A filter question was included to ensure that the respondents were civil servants in Indonesia. The second part included questions on the independent and 
dependent variables that were tested in the survey. The questions covered all the constructs, namely flexible working arrangements, work-family conflicts, work pressure, and organizational commitment. A five-point Likert-type scale was used to measure the respondent's level of agreement or disagreement with each question. The questions were adapted from past studies. Flexible working arrangement questionnaires are mainly adapted from Albion (2005). The questions were meant to measure the general benefit the civil servant receives and how they react to the benefits. The study by Netemeyer et al. (1996) provided the questions for work-family conflict. The questions measured the employees' attitudes and behaviours towards the two roles in the civil servants' lives. In order to measure the amount of job stress, the study used the scale by Parker and DeCotiis (1983). Lastly, the questionnaires for organizational commitment were adapted from Meyer et al. (1993) to measure civil servants' loyalty towards their current organization.

\subsection{Data Collection and Preliminary Checking}

The global pandemic happened during the data collection period. Due to restrictions, the questionnaires were fully distributed online with the help of Google Forms. Through social media usage as the medium to reach out to target respondents, the survey had 417 respondents in 45 days. A total of 17 questionnaires were removed due to missing data, and 400 questionnaires met the sampling target and were used for further analysis. In this study, ethical considerations were strictly observed, where the respondents were not in any way forced to fill the survey, and their confidentiality and their privacy are strictly maintained.

\subsection{Data Analyses and Hypothesis Testing}

The survey responses were edited and coded before the data analysis was done using the IBM SPSS tool (Version 25). Descriptive statistics were generated to describe the respondents' characteristics. The frequency analysis provided a feel of the data. Thereafter, reliability and normality testing was done to check the data's normal distribution and internal consistency. Hypothesis testing was based on Pearson's correlation analysis results as there was more than one dependent variable.

\section{Results}

\subsection{Demographic Characteristics}

Based on the gender profile, most of the respondents were males (51\%). The age group of the respondents was almost equally divided. Most of the respondents were aged between 40-50 years old $(32.5 \%)$, followed by employees above 50 years old (32\%). Another $25 \%$ fell into the age group between 30-40 years. Lastly, $10.5 \%$ fell in the age group between 20-30 years old. The marital status of the respondents indicates that most of them are married $(84.8 \%)$. Based on the results, most of the respondents were from the Sulawesi (75.3\%). All the respondents were employed as civil servants in Indonesia.

Table1. Reliability Testing 
Flexible Working Arrangement

Work-Family Conflict

.855

Work Pressure

.786

Organizational Commitment
.805

2021, Vol. 11, No. 2

\subsection{Reliability Analysis}

Reliability analysis was used to check whether the study's variable is reliable and can be used in the overall research (Pallant, 2013). The measurement was based on the value of Cronbach alpha. The closer the Cronbach alpha value to 1, the more reliable the items of the variables are (Pallant, 2013). As a rule of thumb, the Cronbach alpha value should be equal to or exceeds 0.7. In this study, the Cronbach alpha of all variables was above 0.7 . Therefore, the data was consistent, and the reliability of the data was not violated.

Table 2. Kurtosis and Skewness

\begin{tabular}{lll}
\hline Variable & Skewness & Kurtosis \\
\hline Work-Family Conflict & -.393 & .328 \\
Work Pressure & -.273 & .199 \\
Organizational Commitment & -.435 & .474 \\
Flexible Working Arrangement & -.072 & .209 \\
\hline
\end{tabular}

\subsection{Normality Test}

The Skewness and kurtosis measures were used to test the normality of data distribution. Skewness and kurtosis were utilized to understand the data distribution shape and measure the data's tail shape. The normal value range for skewness and kurtosis should be between +1 and -1 (Hair et al., 2015). All values fall within the standard range, and therefore the normality of data was not violated. The skewness value was negative, and this shows a left skewness.

Table 3. Pearson Correlation Coefficient

\begin{tabular}{llllll}
\hline & & 1 & 2 & 3 & 4 \\
\hline 1. Work-Family & $\begin{array}{l}\text { Pearson Correlation } \\
\text { Cig. (2-tailed) }\end{array}$ & 1 & & & \\
& & & & \\
& Pearson Correlation & $.427^{* *}$ & 1 & & \\
2. Work Pressure & Sig. (2-tailed) & .000 & & & \\
& & & & \\
3. Organizational & Pearson Correlation & $-.193^{* *}$ & $-.111^{*}$ & 1 \\
Commitment & Sig. (2-tailed) & .000 & .026 &
\end{tabular}




$\begin{array}{llllll}\text { 4. Flexible Working } & \text { Pearson Correlation } & .060 & .074 & .164^{* *} & 1 \\ \text { Arrangements } & \text { Sig. (2-tailed) } & .233 & .140 & .001 & \end{array}$

**. Correlation is significant at the 0.01 level (2-tailed).

*. Correlation is significant at the 0.05 level (2-tailed).

\subsection{Pearson Correlation Test}

A measure of the frequency and direction of the association that occurs between two continuous variables is Pearson's correlation. The coefficient called the Pearson correlation coefficient is denoted as $r$ (Pallant, 2013). Its value can range from -1 for a perfect linear negative relation to +1 for a perfect linear relationship (Pallant, 2013). In this study, the Pearson Correlation Test was used to analyze the strength of a relationship between independent and dependant variables. The correlation coefficient and the significance between the independent and dependent variables are reflected in the table above. The Pearson correlation value and the $\mathrm{p}$-value for organizational commitment indicate a positive and significant correlation with the dependent variable. Meanwhile, work-family conflict and work pressure showed a nonsignificant correlation ( $p>0.05)$. Therefore, only hypothesis $\mathrm{H} 3$ was supported. Hypothesis $\mathrm{H} 1$ and $\mathrm{H} 2$ were not supported. The summary of results is shown in the table below.

Table 4. Hypotheses Result Summary

\begin{tabular}{lll}
\hline Developed Hypotheses & Relationship & $\begin{array}{l}\text { Result of } \\
\text { Hypotheses }\end{array}$ \\
\hline $\begin{array}{l}\mathbf{H}_{1} \text { : There is a correlation between flexible working } \\
\text { arrangement and work-family conflict }\end{array}$ & No Correlation & Rejected \\
$\begin{array}{l}\mathbf{H}_{\mathbf{2}} \text { : There is a correlation between flexible working } \\
\text { arrangements and work pressure. }\end{array}$ & No Correlation & Rejected \\
$\begin{array}{l}\mathbf{H}_{\mathbf{3}} \text { : } \text { There is a correlation between flexible working } \\
\text { arrangements and organizational commitment. }\end{array}$ & Moderate Correlation & Supported \\
\hline
\end{tabular}

\section{Discussion, Implications, and Recommendations}

\subsection{Discussion}

The first research objective was to examine the correlation between flexible working arrangements and work-family conflict among Indonesia's civil servants. It was expected to indicate that if the flexible working arrangement were implemented, it would help reduce the civil servants' work-family conflict level (Choo, Desa, and Asaari, 2016; Dex \& Smith, 2002). Instead, the findings deviated from the expected results. Specifically, flexible working hours were expected to be linked strongly to reducing work-family conflict (Masuda et al., 
2012; White et al., 2003). Some past studies have also found an insignificant relationship between flexible working arrangements and work-family conflict (e.g., Allard, Haas, and Philip Hwang, 2007). Past researchers have also cautioned against the use of flexible working arrangements to minimize work-family conflict (Hyman et al., 2003). The first reason for the deviation can be due to gender. This study did not differentiate between men and women. For instance, Allard, Haas, and Philip Hwang (2007) found that the provision of flexible working hours had no effect on work-to-family conflict experienced by managerial fathers. The study by White et al. (2003) revealed that men might use flexible working arrangements to increase working hours. The results of the studies by Chung and Lippe (2018) further confirmed that in understanding the outcomes of flexible working arrangements, gender matters. Another possible explanation is the organizational culture. Chung and Lippe (2018) stated that working from home can either lower or increase work-family conflict among men and women. The relationship between working from home and work-family conflict can be moderated by the organizational contexts such as a supportive organizational culture (Chung and Lippe, 2018). The cultural difference found in Indonesian families allows civil servants to focus on career advancement as it is strongly supported by their families (Afrianty, 2013). Therefore, the support provided by family members such as grandparents can reduce the effects of work-family conflict.

The second research objective was to examine the correlation between flexible working arrangements and work pressure, including stress. The results revealed that flexible working arrangement was not significantly correlated to work pressure. This again deviated from the results found in past studies (e.g., Kelliher and Anderson, 2010; Shagvaliyeva and Yazdanifard, 2014). Implementation of flexible working arrangements was expected to lower work-family conflict and improve the well-being of employees. As explained by Haley and Miller (2015), a greater flexibility level was expected to reduce work pressure and the resulting stress experienced by employees. The first possible reason for the deviation can be the nature of the flexible work initiative. Variations in the effect on work pressure depend on the nature of the flexible work initiative (Russell et al., 2007). Another factor is the amount of job control and resources the employees have. For instance, employees with sufficient job resources can adapt to job demands and handle work pressure well (Lott, 2017). Higher levels of job controls that include flexitime and working time autonomy can enable employees to cope better with work pressures (Lott, 2017). Another possible reason cited is the level of discipline. Lower levels of discipline may allow employees just to mark attendance and attend to other non-work-related tasks (Frinaldi, 2012). Lack of supervision, especially in small cities, can lead to employees setting their deadlines to accomplish tasks (Agus et al., 2018). In such circumstances, civil servants will work only with their own rhythm with no pressure felt from or conflict (Baderi, 2019).

The third research objective was to examine whether the flexible working arrangement is correlated with organizational commitment. The results revealed that there was a moderate correlation between the two variables. The result explains that if the flexible working arrangement is implemented, the civil servants will perceive it as a form of appreciation and value that the employer place in them. This will lead to higher levels of trust and commitment 
and job satisfaction. The results are consistent with past studies (Ross and Ali, 2017; Gudep, 2019; Choo Desa and Asaari, 2019). Further to the results of this study and as explained by Choo et al., 2016), flexibility and supportive work policies can be the best predictors of an employee's organizational commitment. The study by Ross and Ali (2017) examined the commitment factors amongst ICT workers, and the study confirmed that flexible work arrangement was a significant predictor of organizational commitment. The findings of this study are also aligned with the Social Exchange Theory (SET). The provision of flexibility and a supportive work environment by the employer results in a safe and healthy workplace. The employees will reciprocate by showing more commitment and other desirable outcomes, such as lower turnover intention (Paille' et al., 2015). Therefore, flexible work arrangements are essential to increase the organizational commitment levels of civil servants in Indonesia.

\subsection{Conclusion}

This study examined the impact of flexible working arrangements in the public sector in Indonesia. This study reinforces some aspects of flexible working arrangements raised in past studies and extends further understanding of flexible working arrangements in the public sector. The key finding that corroborates the perceived organizational support theory was the impact of flexible working arrangements on organizational commitment. The Perceived Organizational Support Theory states that employees' perception concerning the extent to which the organization values their contribution and cares about their well-being will lead to higher levels of job satisfaction and commitment (Eisenberger, Huntington, Hutchinson, \& Sowa, 1986). This points to the central role of owner-managers in implementing flexible working arrangements. Through flexible working arrangements, employees feel valued, and this leads to employees' reciprocation and obligation to help the organization reach its objectives and their affective commitment to the organization. Researchers and scholars are also in the contention that the provision of flexible working arrangements leads to several positive outcomes that include job satisfaction, commitment, return on labour, and retention of employees (Kotey and Sharma, 2019; Anderson and Keller, 2009; Posthuma et al., 2013; Cegarra-Leiva et al., 2012; Wang et al., 2011). However, this study found that flexible working arrangements did not have a significant impact on work pressure and work-life conflict. The variation could be due to the nature of work or organizational culture. As stated by Russel et al. (2007), variations in the effect on work pressure depend on the nature of the flexible work initiative (Russell et al., 2007). Another reason can be the organizational culture. Chung and Lippe (2018) asserted that the relationship between working from home and work-family conflict could be moderated by the organizational contexts such as a supportive organizational culture.

\subsection{Implications}

There were several practical implications of this study. This study provided government organizations and public service employees with more knowledge regarding flexible work arrangements that can affect employee commitment. The result supported the notion that the employees can increase their commitment towards the organization by implementing flexible working arrangements. Therefore, the results clearly showed that organizational commitment 
could be increased through flexible working arrangements. Organizations and human resource managers should implement and support flexible working policies and procedures that include time restrictions and time autonomy-related policies to improve employees' organizational commitment. For successful implementation, the policies must be clearly communicated, and proper performance measurement must be in place. Evaluating and monitoring such policies' success is necessary as there is a possibility that some employees can abuse such policies. Successful implementation is expected to increase employee commitment, job satisfaction and reduced turnover intention. There were also some contributions from theoretical and academic perspectives. The results will cover the research gap identified in this study and add to the current knowledge body. This study also found that flexible work arrangements do not have a significant relationship with work-family conflict and work pressure. Past studies have also shown inconsistent results. Academicians can extend the results of this study or replicate its different set of respondents.

\subsection{Limitations and Recommendations for Future Research}

There are several limitations in this study that help to set the direction and recommendations for future studies. Firstly, the study only examined formal flexible working arrangements. The potential impact of informal working arrangements was not examined. It is possible that employees react differently to formal and informal working arrangements. Therefore, future studies should examine both formal and informal flexible working arrangements. Secondly, this study did not look at the differences that can arise out of categorical variables such as age and gender. There can be differences in the outcomes of flexible working arrangements arising from differences in gender or age. For instance, there can be differences between men and women towards flexible working arrangements and the related outcomes. Future studies should incorporate categorical variables to test the differences. Categorical variables can also act as moderators. Thirdly, the dimensions of flexible working arrangements were not examined separately. The effect of each dimension may have different outcomes. Therefore, it is recommended that future studies consider the dimensions of flexible working arrangements.

\section{References}

Agus, A. A., Husnayani, \& Rifdan. (2018). Fungsi Pengawasan dalam Kinerja Pegawai Negeri Sipil di Kantor Bupati Kabupaten Soppeng. Jurnal Tomalebbi, 1, 13-34.

Ajayi, M. P., \& Abimbola, O. H. (2013). Job satisfaction, organizational stress and employee performance: A study of NAPIMS. Ife PsychologIA: An International Journal, 21(2), 75-82.

Albion, M. J. (2005). A Measure of Attitudes Towards Flexible Work Options. Australian Journal of Management, 29(2), 275-294. https://doi.org/10.1177/031289620402900207

Allard, K., Haas, L., \& Philip Hwang, C. (2007). Exploring the paradox: Experiences of flexible working arrangements and work-family conflict among managerial fathers in Sweden. Community, Work and Family, 10(4), 475-493. https://doi.org/10.1080/13668800701575135 
American Afrianty, T. W. (2013). Work-Life Balance Policies in The Indonesian Context, Western Australia: Curtin University.

Anderson, D., \& Kelliher, C. (2009). Flexible working and engagement: The importance of choice. Strategic Harvard Business Review, 8(2), 13-18. https://doi.org/10.1108/14754390910937530

Atkinson, C., Lucas, R., \& Hall, L. (2011). Flexible working and happiness in the NHS. Employee Relations, 33(2), 88-105. https://doi.org/10.1108/01425451111096659

Baderi, F. (2019). Neraca: Producktivitas PNS Saat Ini? http://neraca.co.id/article/112979/produktivitas-pns-saat-ini

Balancing work and family after childbirth: A longitudinal analysis. Women's Health Issues, 21(1), 19-27. https://doi.org/10.1016/j.whi.2010.08.003

Berg, P., Kossek, E. E., Misra, K., \& Belman, D. (2014). Work-life Flexibility Policies: Do unions affect employee access and use? Industrial \& Labor Relations Review, 67(1), 111-137. https://doi.org/10.1177/001979391406700105

Bohle, P. (2016). Work-Life Conflict in 'Flexible Work': Precariousness, Variable Hours and Related Forms of Work Organization. In: Social and family issues in shift work and nonstandard working hours. Cham: Springer, pp. 91-105. https://doi.org/10.1007/978-3-319-42286-2_5

Cegarra-Leiva, D., Sanchez-Vidal, M. E., \& Cegarra-Navarro, J. G. (2012) Work life balance and the retention of managers in Spanish SMEs. The International Journal of Human Resource Management, 23(1), 91-108. https://doi.org/10.1080/09585192.2011.610955

Choo, J. L. M., Desa, N. M., \& Asaari, M. H. A. H. (2016). Flexible working arrangement toward organizational commitment and work-family conflict. Studies in Asian Social Science, 3(1), 21-36. https://doi.org/10.5430/sass.v3n1p21

Chung, H., \& Van der Lippe, T. (2018). Flexible working, work-life balance, and gender equality: Introduction. Social Indicators Research, 151(2020), 365-381. https://doi.org/10.1007/s11205-018-2025-x

Dex, S., \& Smith, C. (2002) The nature and pattern of family friendly employment policy in Britain, Bristol/York: The Policy Press/Joseph Rowntree Foundation.

Eisenberger, R., Hungtington, R., Hutchison, S., \& Sowa, D. (1986). Perceived Organizational Support. Journal of Applied Psychology, 71, 500-507. https://doi.org/10.1037/0021-9010.71.3.500

Frinaldi, A. (2012). Analisis budaya kerja disiplin pegawai negeri sipil: studi pada beberapa pemerintah Daerah di Sumatera Barat. Jurnal Ilmu Administrasi Negara, 11(1), 123-140.

Ghani, R. A., Nordin, F., \& Mamat, L. (2004). Organizational commitment among the academic staff in the Distance Education Program. The International Journal of Education Development, 1, 29-43. 


\section{Macrothink}

International Journal of Human Resource Studies

ISSN 2162-3058

2021, Vol. 11, No. 2

Grice, M. M., McGovern, P. M., Alexander, B. H., Ukestad, L., \& Hellerstedt, W. (2011).

Balancing work and family after childbirth: A longitudinal analysis. Women's Health Issues, 21(1), 19-27.

Gudep, V. K. (2019). An Empirical Study of The Relationships between The Flexible Work Systems (FWS), Organizational Commitment (O.C.), Work Life Balance (WLB) and Job Satisfaction (J.S.) For the Teaching Staff in The United Arab Emirates (UAE). International Journal of Management, 10(5), 11-27. https://doi.org/10.34218/IJM.10.5.2019.002

Hair Jr., J. F. et al. (2015). Essentials of business research methods. 2nd ed. London: Routledge. https://doi.org/10.4324/9781315716862

Haley, M. R., \& Miller, L. A. (2015). Correlates of flexible working arrangements, stress, and sleep difficulties in the U.S. workforce: does the flexibility of the flexibility matter? Empirical Economics, 48(4), 1395-1418. https://doi.org/10.1007/s00181-014-0836-4

Hämmig, O., \& Bauer, G. F. (2014). Work, work-life conflict and health in an industrial work environment. Occupational Medicine, 64(1), 34-38. https://doi.org/10.1093/occmed/kqt127

Hill, J. E., Jacob, J., Shannon, L, Brennan, R, Blanchard, V., \& Martinengo, G. (2008). Exploring the relationship of workplace flexibility, gender, and life stage to family-to-work conflict, and stress and burnout. Community, Work \& Family, 11(2), 165-181. https://doi.org/10.1080/13668800802027564

Hofäcker, D., \& König, S. (2013). Flexibility and work-life conflict in times of crisis: a gender perspective. International Journal of Sociology and Social Policy, 33(9/10), 613-635. https://doi.org/10.1108/IJSSP-04-2013-0042

Hyman, J., Baldry, C., Scholarios, D., \& Bunzel, D. (2003). Work-life imbalance in call centres and software development. British Journal of Industrial Relations, 41(2), 215-239. https://doi.org/10.1111/1467-8543.00270

Kattenbach, R., Demerouti, E., \& Nachreiner, F. (2010). Flexible working times: effects on employees' exhaustion, work-nonwork conflict and job performance. Career Development International, 15(3). 279-295. https://doi.org/10.1108/13620431011053749

Kelliher, C., \& Anderson, D. (2010). Doing more with less? Flexible working practices and the intensification of work. Human relations, 63(1), 83-106. https://doi.org/10.1177/0018726709349199

Ketchand, A. A., \& Strawser, J. R. (2001). Multiple dimensions of organizational commitment: Implications for future accounting research. Behavioral Research in Accounting, 13(1), 221-251. https://doi.org/10.2308/bria.2001.13.1.221

Kossek, E. E., \& Michel, J. S. (2011). Flexible work schedules. In Zedeck S. (Ed.), Handbook of industrial and organizational psychology: Building and developing the organization (pp.535-572). Washington, DC: American Psychological Association. https://doi.org/10.1037/12169-017 
Kotey, B. A., \& Sharma, B. (2019). Pathways from flexible work arrangements to financial Performance. Personnel Review, 48(3), 731-747. https://doi.org/10.1108/PR-11-2017-0353

Krejcie, R. V., \& Morgan, D. W. (1970). Determining sample size for research activities. Educational and psychological measurement, 30(3), 607-610. https://doi.org/10.1177/001316447003000308

Kremer, I. (2016). The relationship between school-work-family-conflict, subjective stress, and burnout. Journal of Managerial Psychology, 31(4), 805-819. https://doi.org/10.1108/JMP-01-2015-0014

Kwon, M. (2019). Effects of recognition of flexible work systems, organizational commitment, and quality of life on turnover intentions of healthcare nurses. Technology and Health Care, 27(5), 499-507. https://doi.org/10.3233/THC-191734

Kwon, M., Cho, Y. J., \& Song, H. J. (2019). How do managerial, task, and individual factors influence flexible work arrangement participation and abandonment? Asia Pacific Journal of Human Resources, 1(2019), 1-24. https://doi.org/10.1111/1744-7941.12251

Lee, S. Y., \& Hong, J. H. (2011). Does family-friendly policy matter? Testing its impact on turnover and performance. Public Administration Review, 71(6), 870-879. https://doi.org/10.1111/j.1540-6210.2011.02416.x

Lott, Y. (2017). Stressed despite or because of flexible work arrangements? Flexible work arrangements, job pressure and work-to-home conflict for women and men in Germany (No. 046). Working Paper Forschungsförderung.

Mansoor, M., Fida, S., Nasir, S., \& Ahmad, Z. (2011). The impact of job stress on employee job satisfaction a study on telecommunication sector of Pakistan. Journal of Business Studies Quarterly, 2(3), 50-56.

Masuda, A. D., Poelmans, S. A., Allen, T. D., Spector, P. E., Lapierre, L. M., Cooper, C. L., ... Lu, L. (2012). Flexible work arrangement availability and their relationship with work-to-family conflict, job satisfaction, and turnover intentions: A comparison of three $\begin{array}{llll}\text { country clusters. } & \text { Applied } & \text { 1-29. }\end{array}$ https://doi.org/10.1111/j.1464-0597.2011.00453.x

Matondang, D. (2017). detiknews: Polling: Polisi dan Rekrutmen CPNS Sektor Terkorup di Indonesia.

https://news.detik.com/berita/d-3567421/polling-polisi-dan-rekrutmen-cpns-sektor-terkorup-d i-indonesia

Meyer, J. P., \& Allen, N. J. (1991). A three-component conceptualization of organizational commitment. Human Resource Management Review, 1, 61-89. http://dx.doi.org/10.1016/1053-4822(91)90011-Z

Meyer, J. P., \& Herscovitch, L. (2001). Commitment in the workplace: Toward a general model. Human Resource Management Review, 11, 299-326. http://dx.doi.org/10.1016/S1053-4822(00)00053-X 


\section{Ml Macrothink}

International Journal of Human Resource Studies ISSN 2162-3058 2021, Vol. 11, No. 2

Meyer, J. P., Allen, N., \& Smith, C. A. (1993). Commitment to Organizations and Occupations: Extension and Test of a Three-Component Conceptualization. Journal of Applied Psychology, 78(4), 538-551. https://doi.org/10.1037/0021-9010.78.4.538

Netemeyer, R. G., Boles, J. S., \& McMurrian, R. (1996). Development and validation of work-family conflict and family-work conflict scales. Journal of applied psychology, 81(4), 400-410. https://doi.org/10.1037/0021-9010.81.4.400

Nikbakhsh, R., Afarinesh Khaki, A., \& Sharififar, F. (2020). Assessment Factors Related to Turnover Intention in Sports Organizations. Journal of Health Promotion Management, 9(1), $33-41$

O’Driscoll, M. P., Brough, P., \& Kalliath, T. J. (2004). Work/family conflict, psychological well-being, satisfaction, and social support: A longitudinal study in New Zealand. Equal opportunities international, 23(1/2), 36-56. https://doi.org/10.1108/02610150410787846

Paille', P., Grima, F., \& Dufour, M. (2015). Contribution to social exchange in public organizations: examining how support, trust, satisfaction, commitment and work outcomes are related. The International Journal of Human Resource Management, 26(4), 520-546. https://doi.org/10.1080/09585192.2012.654809

Pallant, J. (2013). SPSS Survival Manual. U.K.: McGraw-Hill Education.

Parker, D. F., \& DeCotiis, T. A. (1983). Organizational determinants of job stress. Organizational behaviour and human performance, 32(2), 160-177. https://doi.org/10.1016/0030-5073(83)90145-9

Posthuma, R. A., Campion, M. C., Masimova, M., \& Campion, M. A. (2013). A high-performance work practices taxonomy: integrating the literature and directing future $\begin{array}{llll}\text { research. Journal of } & \text { Management, }\end{array}$ https://doi.org/10.1177/0149206313478184

Putra, L. M. (2016). Kompas: Menpan RB: 64 Persen PNS Hanya Juru Ketik, Bagaimana Negara $\mathrm{Mau}$

Maju. https://nasional.kompas.com/read/2016/10/18/20470811/menpan.rb.64.persen.pns.

Ramasamy, C. (2019, January 28). It is a scandal that working mothers are $40 \%$ more stressed. than other people. The Guardian. https://www.theguardian.com/lifeandstyle/2019/jan/28/scandal-working-mothers-40-per-centmore-stressed-other-people

Rendon, R. A. (2016). Work-Life Balance Among Working Married Women: What Social Workers Need to Know. Unpublished dissertation. California State University, San Bernardino

Ridho, S. L. Z., \& Al Rasyid, M. N. (2010). Partisipasi angkatan kerja perempuan dan rasio jenis kelamin: Studi kasus negara anggota ASEAN. http://www.bappenas.go.id/blog/?p=297

Ross, P., \& Ali, Y. (2017). Normative commitment in the ICT sector: Why professional 
commitment and flexible work practices matter. International Journal of Employment Studies, 25(1), 44.

Russell, H., O'Connel, P. J., \& McGinnity, F. (2007). The Impact of Flexible Working Arrangements on Work-Life Conflict and Work Pressure in Ireland. Gender Work and Organization, 16(1), 73-97. https://doi.org/10.1111/j.1468-0432.2008.00431.x

Saputra, M. B. (2018). The Diplomat: Who Wants to Be an Indonesian Civil Servant? Almost Everyone.

https://thediplomat.com/2018/10/who-wants-to-be-an-indonesian-civil-servant-almost-everyo

Saunders, M., Lewis, P., \& Thornhill, A., (2016). Research methods for business students. Harlow: Financial Times Prentice Hall.

Sekaran, U. (2010). Research methods for business. 5th ed. New York: John Wiley \& Sons.

Shagvaliyeva, S., \& Yazdanifard, R. (2014). Impact of Flexible Working Hours on Work-Life Balance. American Journal of Industrial and Business Management, 4(1), 20-23. https://doi.org/10.4236/ajibm.2014.41004

Solanki, K. R. (2013). Flexitime association with job satisfaction, work productivity, motivation \& employees' stress. Journal of Human Resource Management, 1(1), 9-14. https://doi.org/10.11648/j.jhrm.20130101.12

Sundaresan, S. (2014). Work-life balance-implications for working women. OIDA International Journal of Sustainable Development, 7(7), 93-102.

Tabachnick, B. G., \& Fidell, L, S. (2007). Using multivariate statistics (5th Ed.). Boston: Pearson Education Inc.

Takeuchi, R., Chen, G., \& Lepak, D. P. (2009). Through the looking glass of a social system: cross-level effects of high-performance work systems on employees' attitudes. Personnel Psychology, 62(1), 1-29. https://doi.org/10.1111/j.1744-6570.2008.01127.x

The World Bank (2018). Indonesia - World Bank Open Data - World Bank Group. https://data.worldbank.org/country/Indonesia

The World Bank (2020). The World Bank in Indonesia. https://www.worldbank.org/en/country/indonesia/overview

The World Bank (2018a). Mapping Indonesia's Civil Service. http://documents1.worldbank.org/curated/en/643861542638957994/pdf/126376-Mapping-Ind onesia-Civil-Service-14977.pdf

Thevamanohar, A. (2020, July 15). Millennials, Gen Z view Covid-19 period as opportunity to reset - Deloitte. The EDGE Markets. https://www.theedgemarkets.com/article/millennials-gen-z-view-covid19-period-opportunityreset-\%E2\%80\%94-deloitte

Timms, C., Brough, P., O'Driscoll, M., Kalliath, T., Siu, O. L., Sit, C., \& Lo, D. (2015). Flexible work arrangements, work engagement, turnover intentions, and psychological health. 


\section{Macrothink}

International Journal of Human Resource Studies

ISSN 2162-3058 2021, Vol. 11, No. 2

Asia Pacific Journal of Human Resources, 53(1), 83-103. https://doi.org/10.1111/1744-7941.12030

Tjiptoherijanto, P. (2018). Reform of the Indonesian Civil Service: Looking for Quality. Economics World, 6(6), 433-443. https://doi.org/10.17265/2328-7144/2018.06.002

Torrington, D., Taylor, S., Hall, L., \& Atkinson, C., 2011. Human Resource Management. New Jersey: Financial Times Prentice Hall.

U.N. Women, (2012). Women are integral part of Indonesian success. http://www.unwomen.org/en/news/stories/2012/12/women-are-integral-part-of-indonesian-su ccess

Wang, S., Yi, X., Lawler, J., \& Zhang, M. (2011). Efficacy of high-performance work practices in Chinese companies. International Journal of Human Resource Management, 22(11), 2419-2441.

White, M. et al. (2003). High-Performance Management Practices, Working hours and Work-Life Balance. British Journal of Industrial Relations, 41(2), 175-195. https://doi.org/10.1111/1467-8543.00268

Yapp, R. (2018). Working Women still do housework. Daily Mail http://www.dailymail.co.uk/news/article-206381/Working-women-housework.html

Yoo, M. J., \& Kim, J. K. (2016). A structural model of hospital nurses' turnover intention: Focusing on organizational characteristics, job satisfaction, and job embeddedness. The Journal of Korean Nursing Administration Academic Society, 22(3), 292-302. https://doi.org/10.11111/jkana.2016.22.3.292

\section{Copyright Disclaimer}

Copyright for this article is retained by the author(s), with first publication rights granted to the journal.

This is an open-access article distributed under the terms and conditions of the Creative Commons Attribution license (http://creativecommons.org/licenses/by/4.0/). 